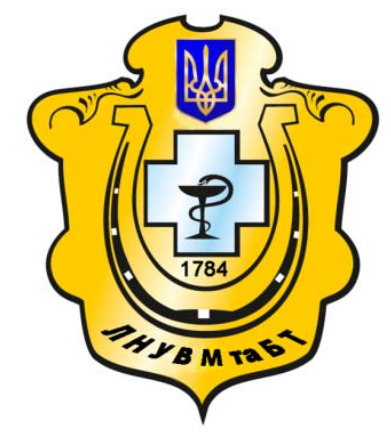

Науковий вісник Львівського національного університету ветеринарної медицини та біотехнологій імені С.З. Гжицького

Scientific Messenger of Lviv National University of Veterinary Medicine and Biotechnologies named after S.Z. Gzhytskyj

doi:10.15421/nvlvet7512

ISSN 2519-268X print

ISSN 2518-1327 online

$\underline{\text { http://nvlvet.com.ua/ }}$

УДК 539.23:621.38:541.64

\title{
Газочутливість плівок поліортотолуїдину
}

\author{
Б.Р. Ціж ${ }^{1,2}$, М.Р. Дзерин ${ }^{1}$, Ю.Ю. Горбенко ${ }^{3}$ \\ marjawka232@ukr.net
}

${ }^{1}$ Львівський національний університет ветеринарної медицини та біотехнологій імені С.3. Гжицького, вул. Пекарська, 50, м. Львів, 79010, Україна;

${ }^{2}$ Kazimierz Wielki University in Bydgoszcz,

30 Chodkiewicza, Bydgoszcz, 85-064 Poland;

${ }^{3}$ Львівський національний університет імені Івана Франка, вул. Грушевського, 4, м. Львів, 79005, Украӥна

Електропровідні полімери, в тому числі поліпірол, поліанілін, політіофен та їхні похідні, використовують як активні шари для газових сенсорів ще з 1980-х років. Порівняно з комериійно доступними сенсорами на основі неорганічних речовин, зокрема високовартісних напівпровідників і оксидів металів, чутливі елементи, отримані на основі спряжених полімерів, привертають увагу завдяки простішому та дешевшому способу виготовлення.

У цій роботі запропоновано чутливі елементи сенсорних пристроїв на основі електропровідного полімеру - поліортотолуїдну (ПоТ) та вивчено зміну оптичних характеристик тонких плівок ПоТ на прозорих поверхнях під впливом газів $\mathrm{NH}_{3}, \mathrm{HCl}, \mathrm{H}_{2} \mathrm{~S}$. Показано, щуо внаслідок дї парів аміаку та хлороводню в оптичних спектрах ПоТ відбуваються суттєві зміни інтенсивності та зсув максимуму оптичного поглинання.

Ключові слова: поліортотолуїдин, тонкі плівки, електрохімічна полімеризачія, хімічне осадження, спектри поглинання, газохромний ефект.

\section{Газочувствительность пленок полиортотолуидина} \author{
Б.Р. Циж ${ }^{1,2}$, М.Р. Дзерын ${ }^{1}$, Ю.Ю. Горбенко
marjawka232@ukr.net \\ ${ }^{1}$ Львовский национальный университет ветеринарной медицины и биотехнологий имени С.3. Гжсицкого, \\ ул. Пекарская, 50, г. Львов, 79010, Украина; \\ ${ }^{2}$ Kazimierz Wielki University in Bydgoszcz, 30 Chodkiewicza, Bydgoszcz, 85-064 Poland; \\ ${ }^{3}$ Львовский национальный университет имени Ивана Франко, \\ ул. Грушевского, 4, г. Львов, 79005, Украина
}

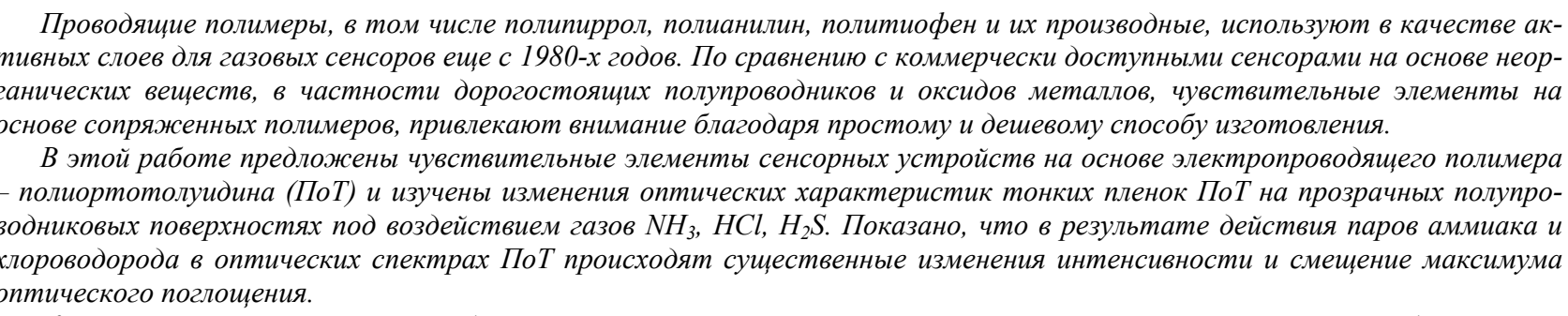

Ключевые слова: полиортотолуидин, тонкие пленки, электрохимическая полимеризация, химическое осаждение, спектры поглощения, газохромний эффект

\section{Citation:}

Tsyzh, B.R., Dzeryn, M.R., Horbenko, Yu.Yu. (2017). Gas sensitivity of poly-ortho-toluidine films. Scientific Messenger LNUVMBT named after S.Z. Gzhytskyj, 19(75), 59-64. 


\title{
Gas sensitivity of poly-ortho-toluidine films
}

\author{
B.R. Tsyzh ${ }^{1,2}$, M.R. Dzeryn ${ }^{1}$, Yu.Yu. Horbenko ${ }^{3}$ \\ marjawka232@ukr.net \\ ${ }^{1}$ Lviv National University of Veterinary Medicine and Biotechnologies named after S. Gzhytskyj, \\ Pekarska Str., 50, Lviv, 79010, Ukraine; \\ ${ }^{2}$ Kazimierz Wielki University in Bydgoszcz, 30 Chodkiewicza, Bydgoszcz, 85-064 Poland; \\ ${ }^{3}$ Ivan Franko National University of Lviv, Hrushevskogo Str., 4, Lviv 79005, Ukraine
}

Conductive polymers, including polypyrrole, polyaniline, polythiophene and their derivatives are used as active layers for gas sensors since the 1980s. In comparison with commercially available sensors based on inorganic materials, including toxic metal oxides, sensors based on conjugated polymers attract attention thanks to a simpler and cheaper method of manufacture.

In this paper the sensitive elements of sensor devices based on conducting polymers - poly-ortho-toluidine have been proposed and the change of optical properties of thin films on transparent surfaces under the influence of gases $\mathrm{NH}_{3}, \mathrm{HCl}, \mathrm{H}_{2} \mathrm{~S}$ have been studied. It is shown that, as a result of the action of ammonia and hydrogen chloride vapor, significant changes in the intensity and displacement of the absorption maximum occur.

The possibility of using PoT films for manufacturing of gas sensors for various purposes, including the monitoring of the food products freshness, the atmosphere and industrial environments have been shown. The next stage of research will be the increasing of the touch sensitivity of polymer films through the synthesis on other substrates and doping with nanoparticles of different nature.

This work was supported by the project of Ministry of Education and Science of Ukraine «Development of new sensory environments for gas analysis in food and processing industry» (state registration number 0116U004740).

Key words: poly-ortho-toluidine, thin films, electrochemical polymerization, chemical deposition, absorption spectra, gasochromic effect

\section{Вступ}

Інтенсивні наукові дослідження електропровідних полімерів викликані особливостями їх фізикохімічних властивостів, в тому числі оптичною активністю у допованому стані, стійкістю до впливу навколишнього середовища, біосумісністю, що зумовлює їх використання у різноманітних галузях - для виготовлення енергозберігаючих пристроїв, аналітичних датчиків, оптоелектронних приладів, сенсорів, світловипромінюючих діодів, антикорозійних фарб і антистатичних плівок. (Elmansour et al., 2007; Chabukswar et al., 2011; Raotole et al., 2016). Газова сенсорика є однією 3 найважливіших галузей сучасної електроніки, що зумовлено необхідністю екологічного контролю, моніторингу газових середовищ у харчовій промисловості тощо (Matindoust et al., 2017). Сенсорні пристрої повинні забезпечувати вибіркову реакцію на певні компоненти, мати високу надійність та відтворюваність результатів. Більшість комерційно доступних сенсорів виготовлені переважно на основі дорогих напівпровідників та оксидів металів і працюють за високих температур. Датчики, що містять електропровідний полімер як активний шар, володіють багатьма вдосконаленими характеристиками - вищою чутливістю, коротким часом відгуку, працюють за кімнатної температури (Bai et al., 2007).

Перспективним для розробки чутливих елементів сенсорних датчиків є поліортотолуїдин (ПоТ). Наявність електрондонорного замінника - метильної групи в орто-положенні до аміногрупи викликає деформацію полімерного ланцюга, що в свою чергу зменшує його жорсткість і сприяє кращій сольватації, а також зумовлює цікаві фізичні та електрохімічні властивості полімеру (Bilal et al., 2014).<smiles>CC1=CC(=Nc2ccc(N[14CH3])cc2C)C=CC1=Nc1ccc(Nc2ccc([Tl])c(C)c2)c(C)c1</smiles>

Рис. 1. Структура елементарної ланки ПоТ

ПоТ складається 3 бензохіноїдних кілець, зв'язаних через аміногрупу. Елементарна ланка полімеру (рис. 1) має 4 структурні одиниці різного ступеня окиснення-відновлення. Якщо кількість окиснених ланок становить 50\% - полімер перебуває у провідному емеральдиновому стані, якщо більшість ланок відновленні - безбарвному лейкоемеральдиновому. У випадку, коли більшість структурних ланок полімеру окиснена - плівка набуває темно-синього кольору i ПоТ переходить у стан перніграніліну.
При взаємодії електропровідних полімерів з газами відбуваються процеси окиснення-відновлення, при цьому змінюється стан полімерів і відповідно колір плівки, що відображається в зміні їхніх спектральних залежностей - виникає газохромний ефект. Найбільш дослідженим в цьому плані є поліанілін (Аксіментьєва, 1998; Tsyzh et al., 2008; 2016). Натомість можливості використання ПоТ як оптичного елемента сенсора хімічних речовин досі остаточно не з'ясовані. 
Використання оптичних елементів сенсорів на основі плівок ПоТ дозволяе визначити наявність та навіть концентрацію газів, що виділяються при порушенні свіжості харчових продуктів, зокрема, дають змогу оцінити свіжість м'яса.

Перспективним методом отримання плівок електропровідних полімерів є електрохімічна полімеризація, яка дає можливість контролювати товщину і оптичні властивості плівок, змінюючи умови електроосадження (Aksimentyeva et al., 2004). Процес проводять в умовах постійного струму або потенціалу, але найбільш зручним і надійним $є$ метод електроосадження 3 циклічною зміною потенціалу. Значний інтерес зосереджено на хімічній полімеризації як способі отримання плівок провідних полімерів внаслідок явних переваг - такий спосіб не залежить від природи, типу субстрата i легуючої домішки (Chabukswar et al., 2014).

Метою даної роботи стало вивчення оптичних спектрів поглинання плівок поліортотолуїдину під дією газів різної природи і прогнозування на цій основі їх можливого застосування в оптичних сенсорах.

\section{Матеріал та методи досліджень}

Плівки ПоТ отримували методами електрохімічної та хімічної окисної полімеризації. Як оптично-прозорі носії використовували скляні пластинки розміром $1 \times 4$ см, вкриті з одного боку тонким провідним шаром $\mathrm{SnO}_{2}$.

Електроосадження полімеру проводили з 0,1 M розчину $о$-толуїдину в $0,5 \mathrm{M}$ сульфатній кислоті в умовах циклічної розгортки потенціалу протягом 50 циклів, межі розгортки від 0 до $1,35 \mathrm{~B}$, швидкість - 50 мВ/с. Як джерело живлення використовували потенціостат ПІ-50 в парі з цифровим контролером MТесh CON-PI-50-2. Процес проводили в стандартній 3електродній комірці, як робочий електрод використовували пластинки $\mathrm{SnO}_{2}$, як допоміжний - платинову дротину, як електрод порівняння - насичений хлорсрібний. Перед роботою електроди знежирювали, промивали дистильованою водою. В ході полімеризації на поверхні $\mathrm{SnO}_{2}$ формувались тонкі плівки ПоТ зеленого (електросинтез) або фіолетового кольору (хімічне осадження). Після нанесення плівок пластинки

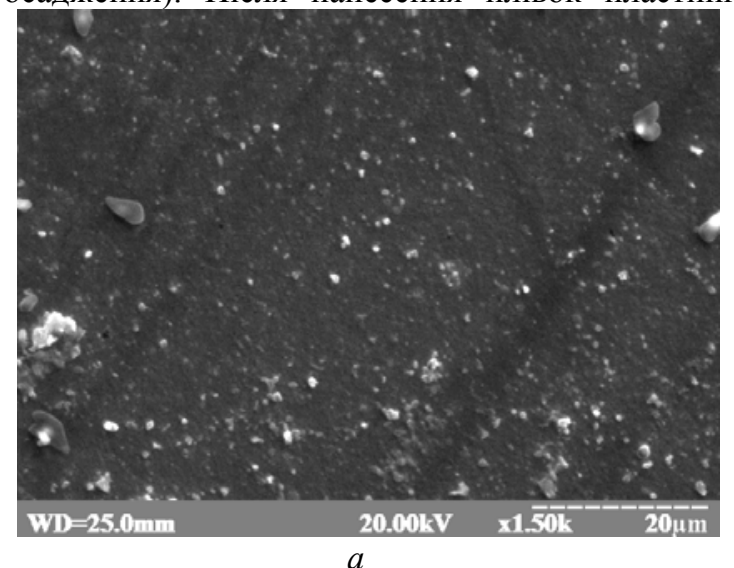

промивали дистильованою водою та висушували при кімнатній температурі.

Методом хімічної полімеризації «іn situ» одержання плівок ПоТ здійснювали $3 \quad 0,1 \mathrm{M}$ розчину $o$-толуїдину в $0,5 \mathrm{M} \mathrm{H}_{2} \mathrm{SO}_{4}$ під дією неорганічного окисника пероксидного типу - 0,1 М амоній пероксидисульфату відповідно до методики (Jin et al., 2000). Bci реактиви, отримані від AldrichCo (Німеччина), використовували без додаткової очистки.

Очищену і знежирену пластинку $\mathrm{SnO}_{2}$ витримували у реакційній суміші упродовж 60 хвилин, після чого пластинку зі сформованою плівкою ПоТ промивали дистильованою водою для видалення залишків мономеру і окисника, висушували при кімнатній температурі упродовж доби і зберігали в ексикаторі.

Для дослідження сенсорних властивостей плівок ПоТ до дії парів $\mathrm{HCl}$ та $\mathrm{H}_{2} \mathrm{~S}$ зразки витримували протягом певного часу $(0,5-3$ хв) у герметичній скляній камері $з$ парами відповідних кислот. Для створення газового середовища аміаку у скляній камері випаровували $1 \%$ розчин гідроксиду амонію.

Вимірювання спектрів оптичного поглинання в середовищі аміаку проводили на модифікованому оптичному двопроменевому спектрометрі Specord M-400 в спектральній області від 300 до 900 нм при кімнатній температурі. Вивчення впливу кислотних газів проводили за допомогою фотоелектроколориметра КФК-3.

Морфологію плівок вивчали за допомогою сканувального електронного мікроскопа REMMA-102-02 та оптичного мікроскопа «Micromed» 3 цифровою фотокамерою «Nicon-2500». Товщина плівок, виміряна 3 використанням мікроінтерферометра МИИ-4, становила близько 560 нм.

\section{Результати та їх обговорення}

Плівки ПоТ, отримані як електрохімічною, так і окисною хімічною полімеризацією, характеризуються однорідною структурою поверхні та майже постійною товщиною. Поруватість не виявлено, спостерігається аморфно-кристалічна мікроструктура плівок полімеру - кристалічні утворення ПоТ, що досить рівномірно розподілені в аморфній матриці полімеру (рис. 2, a, б).

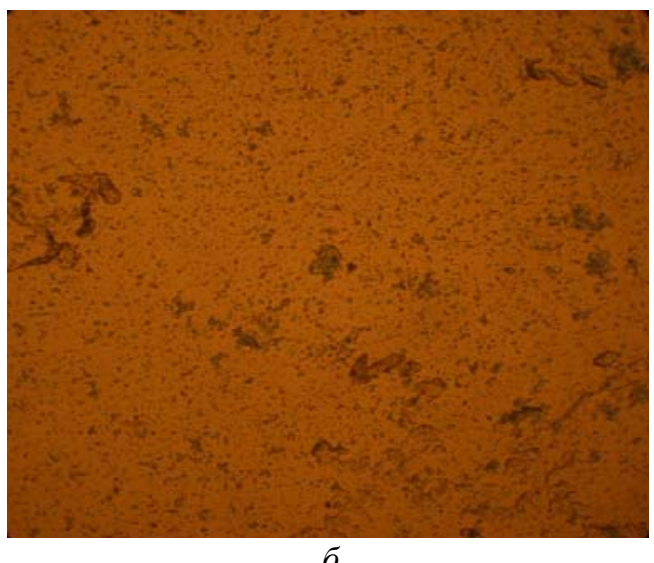

$\sigma$

Рис. 2. СЕМ-мікрофотографія електроосадженого ПоТ на поверхні $\mathrm{SnO}_{2}$ (a) та мікрофотографія поверхні плівки ПоТ, отриманої хімічною полімеризацісю, при застосуванні оптичного мікроскопа (х150) 
Типова спектральна залежність оптичного поглинання плівок поліортотолуїдину, отриманих електрохімічною полімеризацією, представлена на рис. 2. Спектр характеризується трьома смугами поглинання, що характерно для більшості електропровідних полімерів і узгоджується 3 літературними даними (Аксіментьєва, 1998; Konopelnyk O.I. et al., 2016). Перша смуга $\lambda=360-390$ нм характерна для електронних $\pi-\pi^{*}$ переходів у забороненій зоні, друга смуга $\lambda=\sim$ 410-460 нм - для n- $\pi$ * переходу в іміно-хіноїдніих структурах поліаміноаренів, третя широка довгохвильова смуга $\lambda=\sim 790-860$ нм - викликана поглинанням носіїв заряду (поляронів).

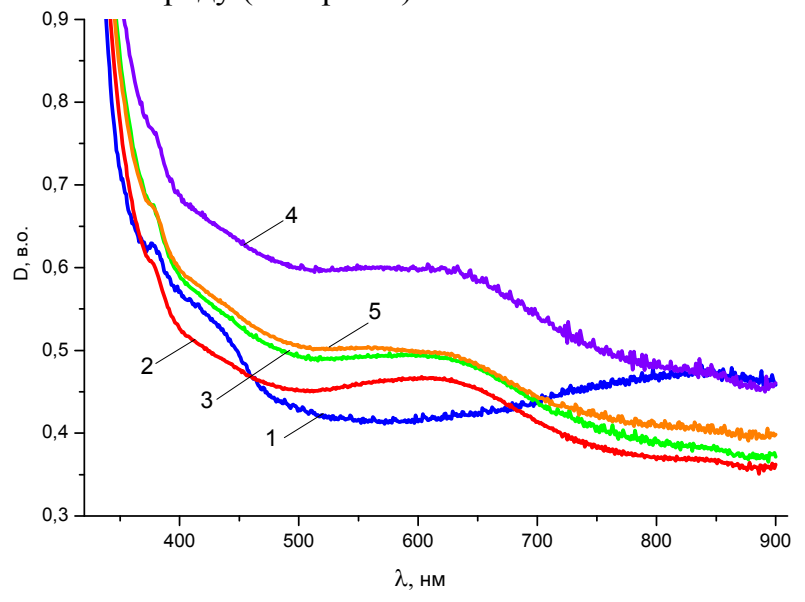

$a$
За подачі аміаку в камеру з електрохімічно одержаною плівкою ПоТ спостерігалась суттєва зміна оптичного спектру - зростання інтенсивності поглинання у всьому вимірювальному діапазоні та зсув максимуму поглинання при $\lambda=850$ нм у бік менших довжин хвиль до $\lambda=580-600$ нм (рис. 2). Цей процес супроводжується зміною кольору плівки від зеленого до синього. Суттєва зміна загального контуру спектру спостерігається вже після дії аміаку впродовж 1 хв., тобто швидкодія оптичного відгуку є достатньо високою.

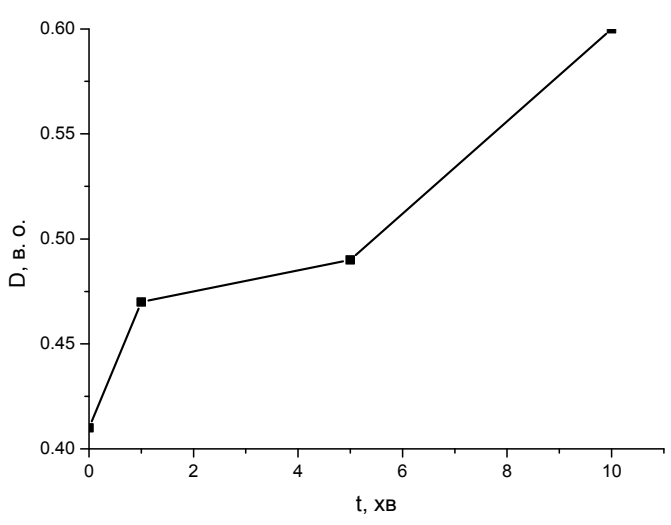

$\sigma$

Рис. 3. (a) Спектри оптичного поглинання плівок ПоТ, отриманих електрохімічною полімеризацісю (1), після дії парів NН3 упродовж: 1 хв. (2), 5 хв. (3), 10 хв. (4), та після відновлення продуванням гарячим повітрям $\left(\mathrm{t}=90{ }^{\circ} \mathrm{C}\right)$ упродовж 15 хв (5). (б) Залежність оптичного поглинання плівки ПоТ від часу контакту 3 аміаком

Для електрохімічно осаджених плівок ПоТ характерний спектр оптичного поглинання з двома смугами (рис. 3), що пов'язано з меншим ступенем окиснення спряженого полімерного ланцюга порівняно $з$ електроосадженим полімером. Спостерігається нівелювання поглинання третьої смуги, гіпсохромний зсув першої смуги, що разом з поглинанням в діапазоні 560580 нм є свідченням того, що в структурі полімеру домінують аміно-хіноїдні структури. Ступінь окиснення полімерного ланцюга не повністю відповідає емеральдиновій солі внаслідок присутності лейкоемеральдинових фрагментів (Konopelnyk et al, 2016).

Важливим завданням моніторингу газових середовищ в харчовій промисловості і довкіллі $є$ визначення кислотних газів, які можуть виділятися в технологічних процесах, зокрема хлороводню, нітрозних газів, сірководню та ін. 3 метою вивчення можливості застосування ПоТ для детектування таких середовищ вивчено вплив газів, які відповідають сильній $(\mathrm{HCl})$ i слабкій $\left(\mathrm{H}_{2} \mathrm{~S}\right)$ кислотам.

При дії парів $\mathrm{HCl}$ забарвлення плівок ПоТ, отриманих методом хімічної полімеризації, змінюється 3 фіолетового на яскраво-зелене і відповідно суттєво змінюються їхні спектри оптичного поглинання (рис. 4).

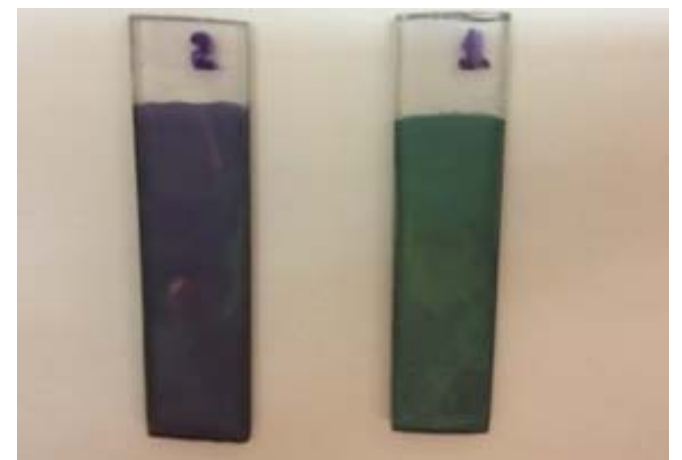

Рис. 4. Зображення плівок ПоТ до (№ 2) i після (№ 1) перебування у парах $\mathrm{HCl}$

Максимум поглинання плівок ПоТ помітно зсувається від 590 нм до 770 нм вже за 30 секунд дії $\mathrm{HCl}$ i досягає 800 нм за 60 секунд (рис. 5). При цьому оптичне поглинання збільшується зі зростанням часу витримки у парах газу. Отже, наявний яскраво виражений газохромний ефект, що може лягти в основу розробки кольорових індикаторів кислотних газів. Контрастність оптичних переходів такого елемента, розрахована як $\Delta \mathrm{D} / \mathrm{D}_{800}$ становить близько $79 \%$ при дії парів $\mathrm{HCl}$ протягом $30 \mathrm{c}$, а уже через 60 с досягає $100 \%$, що є суттєвим показником його чутливості. 


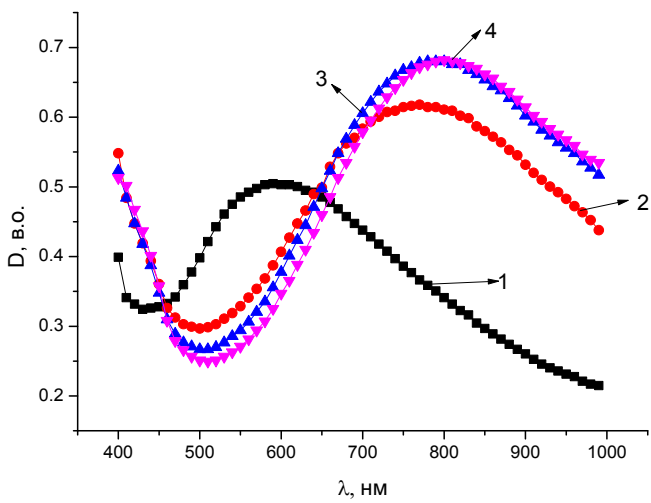

$a$

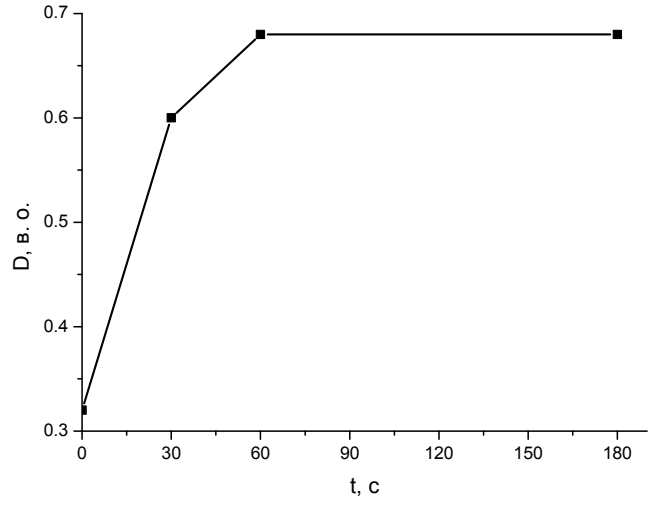

$\sigma$

Рис. 5. (а) Оптичні спектри поглинання плівки ПоТ (1) та при дії парів НCl: 30 с (2), 60 с (3), 180 с (4). (б) Залежність оптичного поглинання плівки ПоТ від часу контакту 3 хлороводнем

Якщо відбувається дія слабокислого газу, то газохромний ефект виявляється у меншій мірі (рис. 6). Такий ефект може бути спричинений низьким ступенем дисоціації $\mathrm{H}_{2} \mathrm{~S}$ i внаслідок цього - малою кількістю протонів, що беруть участь у процесі легування. Це зумовлює набагато менший ступінь допування плівки та відповідно меншу кількість носіїв заряду (поляронів). Контрастність оптичних переходів становить лише близько $8 \%$ при дії парів $\mathrm{H}_{2} \mathrm{~S}$ протягом 30 с, а за більшої тривалості практично нівелюється.

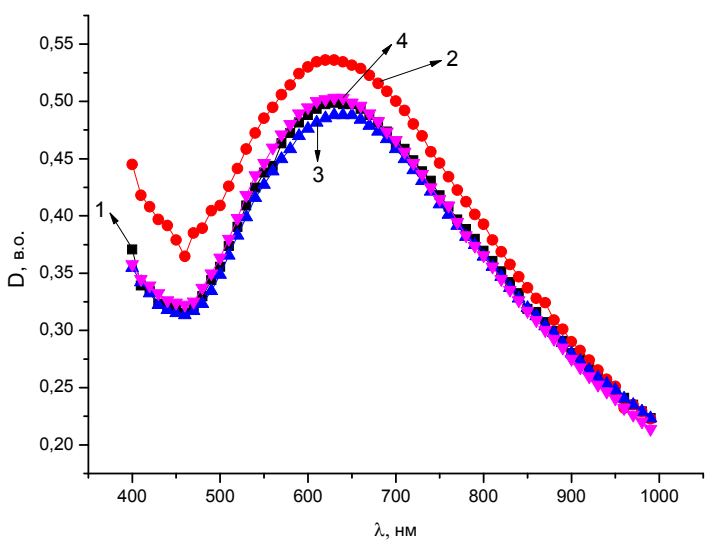

Рис. 6. Оптичні спектри поглинання плівки ПоТ (1) та при дії парів $\mathrm{H}_{2} \mathrm{~S}: 30$ с (2), 60 с (3), 180 с (4)

Отже, при дії газів різної природи на оптичні спектри тонких плівок ПоТ на поверхні $\mathrm{SnO}_{2}$ встановлений протилежний характер газохромного ефекту для лужних (основних) та кислотних газів. Це виявляється у суттєвому (на 230-250 нм) зсуві максимуму оптичного поглинання в бік менших довжин хвиль (при дії аміаку) та не менш суттєвому зсуві максимуму поглинання в бік більших довжин хвиль аж до ближньої інфрачервоної області при дії $\mathrm{HCl}$. При цьому інтенсивність поглинання залежить від часу контакту газу з сенсорним середовищем.
Виявлений ефект може лягти в основу селективного розпізнавання газів різної природи у харчовій промисловості та довкіллі, а також для конструювання оптичних датчиків 3 можливістю контролю концентрації шкідливих викидів у атмосферу та свіжості харчової продукції.

\section{Висновки}

Запропоновано чутливий елемент сенсорного пристрою на основі тонких плівок поліортотолуїдину на прозорих поверхнях, сформованих методами електрохімічної та окисної хімічної полімеризації, що дає змогу значно спростити та здешевити технологію виготовлення. Досліджено оптичні властивості отриманих плівок ПоТ та їхню чутливість до дії газів: $\mathrm{NH}_{3}$, $\mathrm{HCl}, \mathrm{H}_{2} \mathrm{~S}$. Встановлено, що характер оптичних змін в плівках ПоТ залежить від кислотно-основних властивостей газів, що детектуються, і це може бути використаним для селективного визначення основних і кислотних газів у атмосфері та промислових середовищах.

Перспективи подальших досліджень. Показано можливість використання плівок ПоТ для виготовлення сенсорів газів різноманітного призначення, у тому числі для контролю свіжості харчових продуктів та моніторингу стану атмосфери і промислових середовищ. Наступним етапом досліджень стане підвищення сенсорної чутливості плівок полімеру шляхом синтезу на інших субстратах та легування наночастинками різної природи.

Робота виконана в рамках науково дослідного проекту «Розроблення нових сенсорних середовищ для аналізу газів у харчовій і переробній промисловості» (Державний реєстраційний номер 0116U004740).

\section{Бібліографічні посилання}

Aksimentieva, O.I. (1998) Elektrokhimichni metody syntezu i providnist spriazhenykh polimeriv. Lviv: Cvit (in Ukrainian). 
Aksimentyeva, O.I., Konopelnyk, O.I., Grytsiv, M.Ya., Martyniuk, G.V. (2004). Charge transport in electrochromic films of polyorthotoluidine. Functional Materials. 11 (2), 300-304.

Bai, H., Shi, G. (2007). Gas Sensors Based on Conducting Polymers. Sensors (Basel). 7(3), 267-307.

Bilal, S., Farooq, S., Shah, A-H.A., Holze, R. (2014). Improved solubility, conductivity, thermal stability and corrosion protection properties of poly(otoluidine) synthesized via chemical polymerization. Synthetic Metals. 197, 144-153. http://dx.doi.org/10.1016/j.synthmet.2014.09.003

Chabukswar, V.V., Horne, A.S., Bhavsar, S.V., Handore, K.N., Chhattise, P.K., Pandule, S.S., Walunj, D.T., Shisodia, S.U., Citterio, A., Dallavalle, S., Mohite, K.C., Gaikwad, V.B. (2014) A novel enhancement of nanostructure by organic acid dopants in emulsion polymerization of poly(o-toluidine). Journal of macromolecular science, Part A: Pure and applied chemistry. 51, 435-440.

Chabukswar, V., Bhavsar, S., Horne, A. (2011). Organic synthesis and characterization of electrically conducting poly (o-toluidine) doped with organic acid. Chemistry \& Chemical Technology. 5(1), 37-40.

Elmansouri, A., Outzourhit, A., Oueriagli, A., Lachkar, A., Hadik, N., Achour, M.E., Abouelaoualim, A., Berrada, K., Ameziane, E.L. (2007). Spectroscopic characterization of electrodeposited poly(o-toluidine) thin films and electrical properties of ito/poly(otoluidine)/aluminum schottky diodes. Active and Pas- sive Electronic Components. Article ID 17846, 7 pages. doi:10.1155/2007/17846.

Jin, Z., Su, Y., Duan, Y. (2000). An improved optical pH sensor based on polyaniline. Sensors and Actuators. $71,118-122$.

Konopelnyk, O.I., Savytsky, N.S., Aksimentyeva, O.I., Horbenko, Yu.Yu. (2016). The influence of silver nanoparticles on absortion spectra and structure of thin poly(ortho-toluidine) films. Physics and Chemistry of Solid State. 17 (4), 599-603. doi: 10.15330/pcss.17.4.599-603

Matindoust, S., Farzi, A., Nejad, M.B., Abadi, M.H.S., Zou, Z., Zheng, L-R. (2017). Ammonia gas sensor based on flexible polianiline films for rapid detection of spoilage in protein - rich foods. J. Mater Sci: Mater Electron. doi 10.1007/s10854-017-6471-z

Raotole, P.M., Raotole, M.L., Khadayate, R.S., Patl, S.R. (2016). Performance of Poly (Aniline-co-o-Toluidine) Coatings Against Corrosion of Copper. International Journal of Metallurgy and Alloys. 1 (2), 29-40.

Tsizh, B.R., Chokhan, M.I., Konopelnyk, O.I., Poliovyi, D.O. (2008). Sensors based on conducting polyaminoarenes to control the animal food freshness. Mol. Cryst. Liq. Cryst. (497), 254-260.

Tsyzh, B.R., Aksimentyeva, O.I., Olhova, M.R., Horbenko, Yu.Yu. (2016). Sensory properties of polyaniline films, obtained on the optically transparent carriers. Scientific messenger LNUVMBT named after S. Z. Gzhytskyj. 18 (2), 121-125.

Стаття надійшла до редакції 20.02.2017 